\title{
POSSIBILITIES FOR THE GROWTH OF SOCIAL HOUSING WITH THE PARTICIPATION OF DEVELOPERS IN POLAND
}

\author{
Agata Antczak - Stępniak, M.Sc. \\ Department of Investment and Real Estate \\ Faculty of Economics and Sociology \\ University of Lodz \\ e-mail:agata.antczak@onet.eu
}

\begin{abstract}
Development activity, understood as an economic activity consisting of transforming a property so as to induce an increase in value, has been expanding in Poland since the early nineties of the twentieth century. However, in this country, it is an activity associated mainly with the profit which a developer can make from the sale or rental of the transformed property. In the West, however, non-profit development activity, providing mainly housing for rent for people with limited financial resources, has become increasingly popular. Under the current institutional conditions, the growth of this type of activity in Poland seems impossible. In this situation, Social Housing Associations could play a similar role, subject to the extension of the scope of their activities and funding opportunities. Therefore, it is reasonable to put forward the thesis that, in order to make the growth of social housing in Poland more dynamic, it is necessary to expand for the range of SHA activities as well as to initiate non profit development activity based on the model of Western countries. The aim of the paper is to demonstrate the legitimacy of the presented thesis by analyzing the available literature, statistical data and case studies.
\end{abstract}

Key words: development activity, non-profit activity, Social Housing Association.

JEL Classification: L31, L74, R31, R38.

Citation: Antczak - Stępniak A., 2017, Possibilities for the Growth of Social Housing with the Participation of Developers in Poland, Real Estate Management and Valuation, vol. 25, no. 1, pp. 74-83.

DOI: $10.1515 /$ remav-2017-0004

\section{Introduction}

Development activity has been around for many centuries. The first mention of entities purchasing land for the purpose of its division and resale, or of buying townhouses and repairing them to be rented to third parties appeared already in antiquity (PISANI, PISANI 2001, pp. 7-9). Over the years, along with the changes taking place in the global economy, there has been a verification of the functions, objectives and scope of development activity. Depending on the country in which the activity developed, its range may be slightly different, hence the diversification in the definitions of a developer.

The French-language literature points to the fact that the developer, promoteur immobilier in French, implements projects for profit, managing the transformation of immovable capital (land) into flats for sale (SCHOONBRODT 1987, p. 52, compare also: WENDLING 2008, p. 198). In the English-language literature, some definitions emphasize the profit that the developer obtains upon the completion of a project, or the risk that is associated with it (FISHER, MARTIN, MOSBAUGH 1991, p. 51; DAVIS 2007, p. 14), while others completely ignore these issues, focusing only on the scope of the developer's activities (D'ARCY, KEOGH 2002, p. 19; KÄLIN 2005, p. 8). Interestingly, some foreign publications relating to the real estate market or directly to development activities distinguish a group of non-profit developers 
(PEISER, HAMILTON 2015, p. 26). The nature and scope of their operations will be explained later in this publication.

In Poland, although different definitions also exist, in practice, the developer is treated as a commercial entity that creates a vision of a project, and promotes and implements it in order to increase the value of a property, thus consequently - for profit (see: KUCHARSKA - STASIAK 2006, pp. 229-233, compare also: GAWRON 2006, p. 44). This is indicated not only by the definitions of a developer, but also by other publications related to development activity (see: DITTMANN 2014, pp. 1726). In Poland, there is, therefore, no concept of a non-profit developer ${ }^{1}$. At the same time, the possibility of the appearance of such entities in the current Polish institutional conditions is virtually nonexistent. Social Housing Associations (SHAs) are the non - profit entities that implement new housing projects in Poland and, subject to extension of the scope of their activities and funding opportunities, could fulfill a role similar to American non-profit developers.

Therefore, the paper puts forward the concept that, in order to make the growth of social housing in our country more dynamic, it is necessary to expand the range of activities undertaken by SHAs in the near future, as well as to initiate non-profit development activity based on the model of Western countries. The aim of the paper is to demonstrate the legitimacy of the presented thesis by analyzing literature, statistical data and case studies.

\section{The functioning of non-profit developers in the United States}

In the United States, many entities are responsible for the implementation of projects involving the construction of residential buildings. They include small private enterprises, large private corporations of national or international importance, governmental agencies, REITs (Real Estate Investment Trusts), or non-profit developers. In the United States, small private developers play the most important role. They primarily build dwellings for sale in order to make a profit (PEISER, HAMILTON 2015, pp. 23-27). However, apart from privately-owned flats, society also needs flats for rent that would be accessible to people with lower incomes. Their provision is necessary due to the fact that the number of privately-owned flats in the United States is decreasing (they were inhabited by $64.5 \%$ of the population in 2014 , as compared to $69 \%$ in 2004). This is particularly evident in relation to people of African-American (less than $44 \%$ of the population own a flat) and Hispanic origin $(45.4 \%)$. Also, young people under 25 years of age $(21.7 \%)$ and $25-29$ year-olds $(32.7 \%)$ have a significant problem with purchasing their own dwellings (HUD, accessed on 18.08.2015). This is due to the fact that, in 2013 , the average annual income of US households amounted to $\$ 51,939$, i.e. approx. $\$ 4,330$ per month. African Americans had the lowest household incomes - \$34,598 (DENAVAS WALT, PROCTOR 2014, pp. 5-6). It is also worth mentioning that the revenues of nearly $13 \%$ of households did not exceed $\$ 15,000$ per year. Under such conditions, it is difficult to obtain one's own flat. In 2013, the average sale price of a new single-family home was $\$ 319,275$ (U.S. CENSUS, accessed on 1.09.2015), which means that the average household could acquire $1.35 \%$ of the house with their monthly income.

Housing for low-income households can be supplied, among others, by non-profit developers. The modern, non-profit housing sector consists mainly of local Community Development Corporations (CDCs), as well as large, regional and national non-profit organizations (BRATT 2007, p. 6). In fact, nonprofit developers in the USA are derived from three types of entities: social organizations, enterprises dealing solely with housing construction or enterprises involved in the development of specific locations. Many of such entities conduct very diverse activities which consist of: creating a sense of personal responsibility, building work skills, providing programs and services to support people in meeting their basic needs, creating jobs, building the local community, providing opportunities for citizens to become the owners of rented flats or for the development of residential housing by supplying good quality and affordable housing. It is assumed that by increasing the level of professional qualifications of low income people, these organizations contribute to employment growth, which allows people to reach the income levels required to pay for renting a dwelling (BRATT, KEYES 1998, pp. 795-824). Thus, their mission provides them with a strong incentive not to sell the

\footnotetext{
1 The Act of 16 September 2011 on the Protection of Rights of the Buyer of Residential Dwellings or Single-family Homes defines a developer as "an entrepreneur within the meaning of the Act of 23 April 1964 - Civil Code (Journal of Laws. No. 16, item. 93, as amended) who in the course of business activity under a developer contract undertakes to establish the rights referred to in Art. 1 and transfer these rights to the buyer".
} 
flats, but instead hold on to them in order to rent them out to households with lower incomes (BRATT 2007, p. 43).

In the United States, the involvement of non-profit organizations in housing began in the early twentieth century when unsuccessful attempts to limit the profits that private entrepreneurs derived from the construction of housing for rent were made (BRATT 2007, p. 2). According to Friedman, in some cases, the rental model contributed to the formation of slums (FRIEDMAN 1968 pp. 81-82, 87). However, the actual significance of non-profit organizations in the development of social housing has risen over the last few decades. Their activity is a result of the frustrating nature of government housing programs that have not met social expectations, as well as to the feeling that these organizations can provide better housing than state or for-profit developers (BRATT, KEYES 1998, pp. 795-824).

Over the years, various types of federal programs aimed at supporting non-profit entities have operated in the United States. These include: Section 202 (the development of subsidized housing for the elderly and disabled) as well as, later on, Section 221(d) and programs guaranteeing lower than market interest rates on loans, the Neighborhood Self-Help Development for Community/Neighborhood Development Organizations, subsequently replaced by the Community Development Block Grant Program, or the Nehemiah Program. The Nehemiah Program funded nonprofit organizations, which in turn granted interest-free loans of up to $\$ 15,000$ to buyers of homes built under the program (BRATT 2007, pp. 4-5, also see DREIER, HULCHANSKI 1993, pp. 43-80).

Currently, such entities in the United States are an important component of social housing. The resources of social housing include a total of approx. 4.6 million homes, with approx. 1.7 million built by the non-profit sector (PEISER, HAMILTON 2015, p. 26). The basic form of state aid for non-profit organizations that build housing for low-income people is the Low Income Housing Tax Credit (LIHTC) Program. It was created under the Tax Reform Act of 1986 and is to encourage the development of housing for rent for low income people through tax credits for the entities that are owners of the implemented investments. The rules of its operation are somewhat complex. The Treasury Department allocates financial aid to each state at an amount depending on the size of the population (HETTINGER 2005, pp. 13-19). Developers submit their proposals to the relevant government agency granting support in the framework of LIHTC. When their projects are approved, developers seek investors that want to finance the projects in exchange for tax credits. Sometimes, it is investors who seek these types of projects, in which they could invest. A developer who received a loan under LIHTC "syndicates" it to the investor who, in return for cash for the implementation of the project, acquires a reduction in federal income tax (The Low Income Housing Tax Credit...). After the sale of "tax credits", a partnership is set up and an ownership structure is determined, with investors generally owning even over $99 \%$ of the shares, and the rest falling to the project developer. As a rule, not all flats must be rented to people with low incomes, but the higher the number, the more benefits one receives. So far, $40 \%$ of the flats had to be designated for people whose incomes did not exceed $60 \%$ of the average income in a given area, and the rents could be no higher than $30 \%$ of their income. Alternatively, $20 \%$ of these flats should have rents available for those not reaching $50 \%$ of the average income for the area (HETTINGER 2005, pp. 13-19). The investing entity is not involved in the development of the property and property management. The investor obtains tax credits for 10 years, but the completed homes must be rented to people with lower incomes for 15 years. New investments or the revitalization of particular areas can be undertaken within the framework of the program. The amount of the tax credit is connected with the participation of persons with low incomes that the flats are rented to. Hitherto, it depended also on the type of financing. If public funds had been used, the tax credits would have amounted to $4 \%$ of the construction costs (excluding land value), while in the case of a project without the use of federal money, the tax credits reached a value of $9 \%$ of the construction costs (The Low Income Housing Tax Credit...). In recent years, however, significant changes to the terms of the LIHTC Program have been made, the effects of which are currently difficult to predict. The amendments concern, among others, the duration of tax credits (15 years instead of 10), resigning from the $4 \%$ tax credit, and the preferred target groups (KIMURA 2014). It is worth noting that state laws require $10-15 \%$ of LIHTC funds to be allocated for non-profit developers and, in some states, even more. For example, in 2003, 100\% of the funds were allocated for non-profit developers in Rhode Island and Ohio (CHUNG 2004, p. 3).

As indicated in Fig. 1, the number of flats built under the LIHTC Program has been declining in the recent years. The decrease in this number since 2007 was caused, among others, by the bursting of the 
price bubble in the residential real estate market. Fannie Mae and Freddie Mac, the two largest investors in the LIHTC Program, ended up under the strict control of the state shortly after the recession, and many large banks do not want to use tax credits resulting from the financing of housing for rent due to the losses that they had incurred in previous years. The reduction of funding has contributed to a decrease in interest on the part of entities implementing such projects (CLARKE 2015, p. 6).

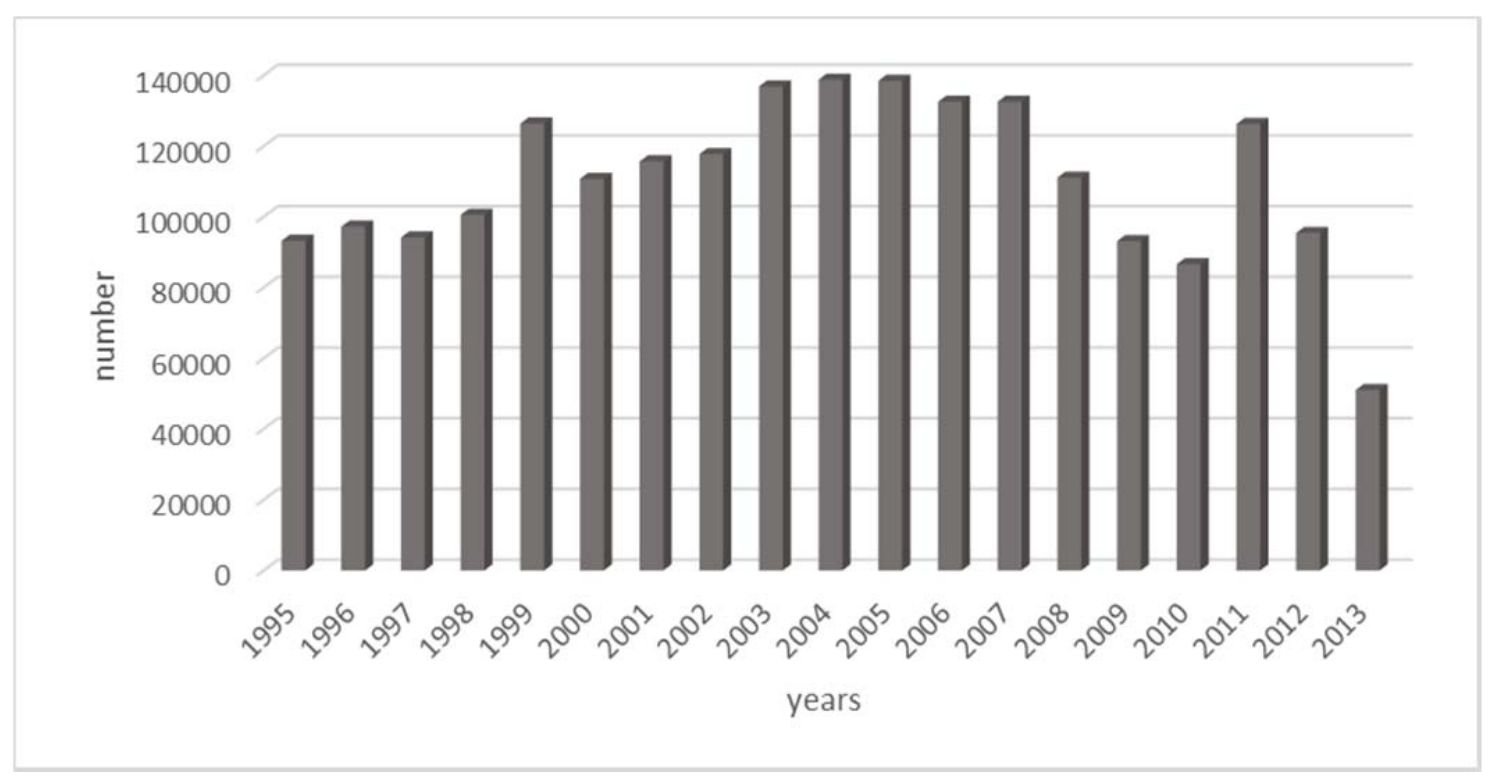

Fig. 1. Number of flats constructed in the framework of the LIHTC Program. Source: author's own compilation based on HUD.

An example of non-profit development activity is, among others, Chinatown CDC. Together with a local partner, it carried out the renovation of a property located at 701 Golden Gate Avenue and Franklin Street in San Francisco, which resulted in the construction of 100 flats for elderly people with very low incomes, including 20 flats for the homeless. In addition, the building also houses premises earmarked for different types of services, a coffee shop, an Internet café and others. Programs aimed at activating the elderly, including computer courses, have also been implemented (Chinatown CDC website, accessed on 23.08.2015).

Another example is Los Angeles Conservancy. This organization was responsible for the project at 28th Street in Los Angeles (YMCA, 28th Street Apartments). Within the framework of the project, a building built in 1926 was renovated, resulting in 49 flats with separate kitchens and bathrooms. These are intended for people with low incomes and young people who are homeless and want to start an independent life. Los Angeles Conservancy deals, in particular, with projects aimed at the preservation and promotion of the cultural heritage of Los Angeles. For this purpose it prepares, among others, educational programs, for middle and high school youth (Los Angeles Conservancy website, accessed on 23.08.2015).

\section{The development of residential construction in Poland after 1989}

In Poland, flats are built by the following groups of entities: individuals, for-profit developers, housing cooperatives, companies, SHAs and municipalities. The importance of particular groups has changed over the years. According to data from the Central Statistical Office, apart from individual construction, housing cooperatives played the largest role for many years. However, in the early twenty-first century, their importance began to decline. At the same time, development activity continued to grow. Initial difficulties arising from restricted access to funding or the number of bankruptcies as a consequence of the lack of experience of some entities have been partly eliminated, and the gradual emergence of foreign entities in the market has forced Polish developers to improve the quality of services (compare: ŁASZEK 2004, pp. 176-177). Currently, in addition to individuals building for their own needs, developers are the group of entities providing the largest part of the supply of new flats. 
In Poland, a developer is a private entity that seeks to achieve substantial profits from the completion of a project. As of today, the concept of a non-profit developer does not exist, while the housing needs of low-income people, which should be largely accommodated by municipalities, are significant. According to the data from the Central Statistical Office of 2011, there is a shortage of approx. 1.1 million flats in Poland, and 15\% of the existing stock is overcrowded or in poor condition (The Housing Situation...2012, p. 3). Such flats, often of substandard nature, are inhabited mostly by people who do not have sufficient financial resources to ensure accommodation adequate to their needs.

It should be noted that the average monthly salary currently stands at just over PLN 4,000. At present, the minimum gross salary is only PLN 1,750, in the case of people taking up employment for the first time it is even as low as PLN 1,400. However, there is no data available on the share of people with the lowest income in the total population. Despite this fact, it has been indicated that an average Pole spends more than $80 \%$ of disposable income, of which basic needs - such as flat maintenance, utilities, food, clothing, education, transport, communication and health - constitute around $76 \%$ of income (Household Budgets... 2014, p. 48). In such a situation, lower income people are often not able to pay even the main expenses, not to mention possess savings. They cannot, therefore, afford to buy a flat or even rent one on a commercial basis. For such people, it is thus necessary to provide housing with the lower rent than that on the market. In Poland, this type of housing can be provided by municipalities, cooperatives (cooperative housing tenancy right) or Social Housing Associations brought to life by the Act of 26 October 1995 on Certain Forms of Support for Residential Construction and Amendments to Certain Legislation. Social Housing Associations, according to the law, are nonprofit entities providing rental housing for households whose income does not exceed 1.3 of the average monthly salary in the region, increased by $20 \%$ for a single-person household, $80 \%$ for a twoperson household, and a further $40 \%$ for every additional person in the case of the household accommodating more people. It is, therefore, a form of construction suitable for households with average incomes. Social Housing Associations can take the form of limited liability companies, joint stock companies or cooperative corporations. Their activity is conducted to the extent specified in the agreement or statue, and their income is spent entirely on statutory activities (Articles 23 - 33 of the Act).

Initially, the role of SHAs was significant. The number of rental social housing completions since 1996 increased up until 2001. Relatively high levels of this type of construction remained until 2006. The activity of SHAs was funded by the National Housing Fund, from resources of the National Economy Bank (Bank Gospodarstwa Krajowego - BGK) specifically dedicated for this purpose. The fund was established in 1996 to serve the needs of implementing the national housing policy. It extended loans to social housing associations and housing cooperatives for residential construction (since 2004 also for purchasing real estate, including buildings for residential use) to a maximum of $50 \%$ (since 1997 of up to $70 \%$ ) of the construction costs. The loans had preferential interest rates, not exceeding the current bill rediscount rate, and, subsequently, even $50 \%$ of the rate, but not less than $3.5 \%$. The repayment period was as long as over 30 years (The Act on Certain Forms...; the Regulation of the Council of Ministers of 7 November 2007...). The financial crisis and the liquidation of the National Housing Fund in 2009 hampered the development of Social Housing Associations. Currently, their importance as the supply side is negligible - in 2014, social housing for rent accounted for only $0.1 \%$ of all the flats completed and $0.007 \%$ of the total housing stock in 2013 in Poland.

After 2009, the National Economy Bank had to allocate funds received from the repayment of loans granted by the National Housing Fund for the implementation of government programs to promote residential construction, and thus, also the program supporting social housing for rent. In order to implement such programs, the minister responsible for public finances was also supposed to allocate state budget funds to increase the statutory fund of the National Economy Bank. However, the program to support social housing for rent never actually began functioning. After the liquidation of the National Housing Fund, the Council of Ministers was supposed to define the conditions for granting preferential loans under this program in the form of a regulation, but this did not happen. There were, therefore, no appropriate legal regulations that would constitute the conditions for granting such assistance. This meant the lack of possibility of funding social rental housing. However, if SHAs are to achieve the objectives for which they were established, they cannot afford to take commercial loans. The need to repay instalments would require raising rents in the rented flats. The rents, however, cannot exceed the value specified by the Act. 
In Poland, there are also other programs to support housing development, for example, the Flat for Youth Program. This program, however, is designed for potential buyers, not for entities building flats. Another example is the Flats for Rent Fund, which is an initiative of the National Economy Bank, though it functions on a commercial basis under the provisions of the Act on Investment Funds, and the rents are too high for people with low and sometimes even average incomes. In 2006, a law was passed about financial support for creating social housing, sheltered housing, and shelters and housing for the homeless. Under its provisions, the Subsidy Fund provides support to municipalities, among others, for the construction of social housing for low-income households. The current stock of this type of housing represents only a few percent of the total housing, and the waiting time for such accommodation is even up to a few years. Further measures enabling the construction of housing for rent for people with lower incomes are thus necessary.

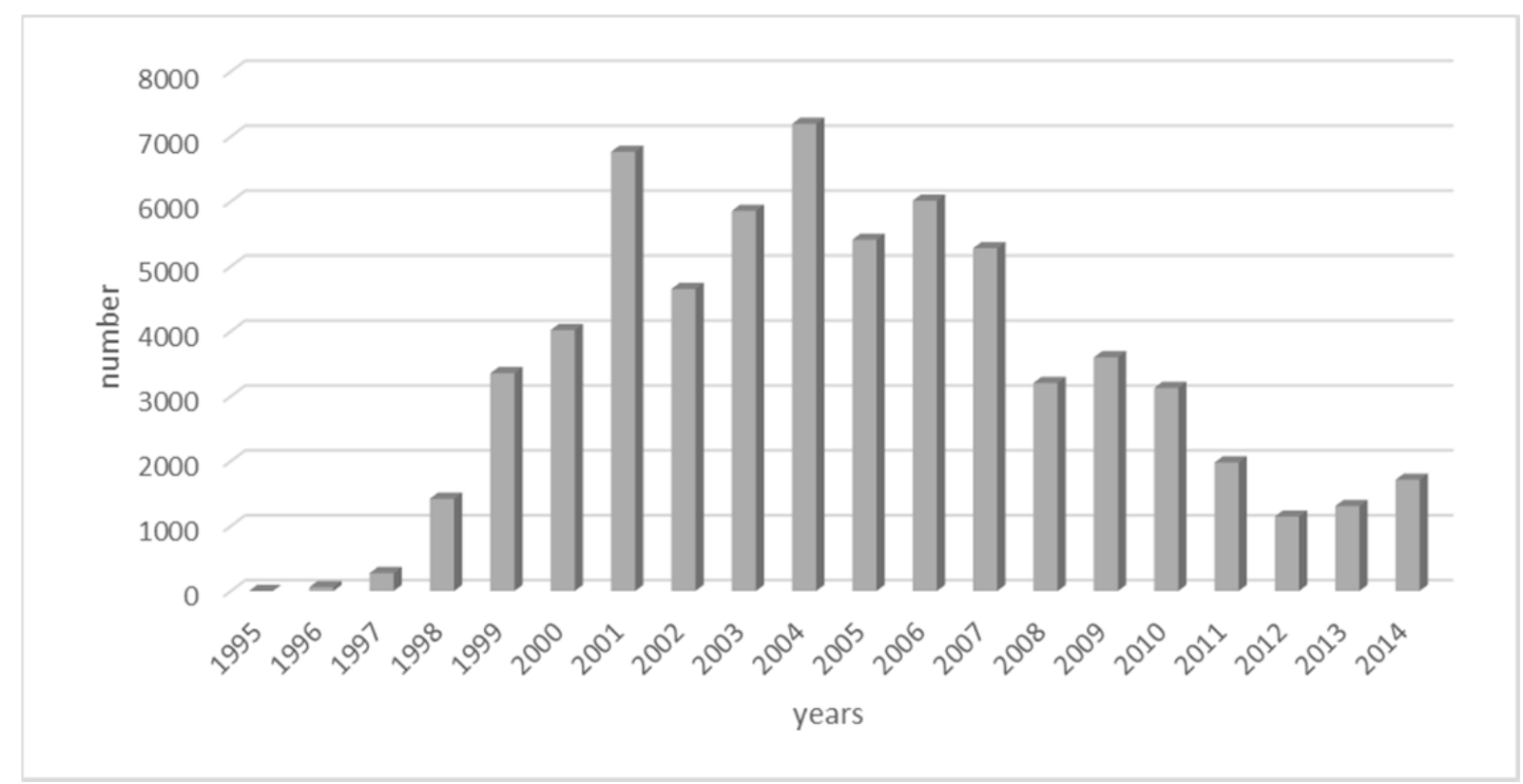

Fig. 2. Number of SHA flats completed in the years 1995-2014. Source: author's own compilation based on BDL.

4. Non-profit development activity and Polish SHAs (similarities, differences and changes needed)

Social Housing Associations presented in the previous section, which are not developers within the meaning of the Act 2011 on the Protection of Rights of Buyers of Residential Dwellings or Singlefamily Homes, cannot, therefore, be called non-profit developers, also for the purposes of foreign literature. The main differences between Polish Social Housing Associations and American non-profit developers have been presented in Table 1. According to the author, the conclusions from this analysis may be of interest to future Polish housing policy.

Table 1

Similarities and differences between non-profit developers and SHAs

\begin{tabular}{lllll}
\hline Items & \multicolumn{2}{c}{ Non-profit developers (USA) } & \multicolumn{2}{c}{ SHAs (Poland) } \\
\hline Similarities & - & & - non-profit \\
& $-\begin{array}{l}\text { require financial support from } \\
\text { government programs }\end{array}$ & $-\begin{array}{l}\text { require financial support from } \\
\text { government programs }\end{array}$ \\
\hline
\end{tabular}

Differences 1) housing activity is often merely a 1) deal solely with housing: supplement to another kind of sociocultural activity

2) build housing for people with the lowest incomes, the disabled, the elderly and the homeless

3) complex form of support: the developer construction and management

2) build housing for people with average incomes

3) form of support: preferential loan awarded directly to SHAs receives assistance under the LIHTC 
Program, sells it to an investor that, in exchange for cash, receives benefits in the form of tax credits

Source: author's own compilation based on literature.

Due to the lack of access to financing, SHAs cannot expand their activities. The amendment to the Act on Certain Forms of Support for Residential Construction of 2009 eliminated the National Housing Fund, and, from that time, the activities of SHAs were to be financed through government programs managed by the National Economy Bank. However, these legal delegations could not be made as a result of objections questioning the possibility of providing preferential financing of social rental housing by the National Economy Bank based on the existing regulations. On 25 October, 2015, amendments to the Act on Certain Forms of Support for Residential Construction came into force. Socalled refundable financing, involving the granting of preferential loans by the National Economy Bank as well as the organization of the issuing of bonds and guaranteeing their purchase under the program of support for residential construction, became the new instrument of support. Financing is to be granted for a maximum period of 30 years and will not exceed $75 \%$ of the costs of implementing the project. The interest rate of preferential loans or bonds in accordance with the amendment will be equal to the 3-month WIBOR rate. The National Economy Bank will receive a subsidy from the Subsidy Fund for interests in the amount of 1.3 percentage points above the rate. In addition to the rules on granting financial assistance, amendments to the Act also changed some of the rules of SHAs. Flats completed in the framework of repayable financing cannot be converted to separate privatelyowned properties and the set rent cannot exceed $5 \%$ of the replacement value. At the same time, changes in the amount of participation have been introduced. Currently, it cannot exceed $25 \%$ of the construction costs (The Act of 10 September 2015 Amending the Act on Certain Forms...). There is, therefore, a chance that the number of flats built by SHAs in the coming years will begin to increase.

However, SHAs, even in this modified form and with better access to financing, will not solve the biggest problem of Polish housing - the shortage of adequate quality housing available to people with the lowest incomes (the young, elderly and disabled), which non-profit developers in the States deal with. In Poland, these types of flats are provided by municipalities. Their number is, however, insufficient, and many are in bad technical condition. As indicated by Eurostat in 2013, 67.8\% of Polish flats available for rent at a reduced rental rate were overcrowded. This means 1.1 rooms per person, with the EU average being 1.6, and in the case of rented flats - 1.5. In addition, the data indicate that slightly more than $10 \%$ of Poles reside in flats in bad technical condition (Eurostat). In the city of Lodz, $11 \%$ of the buildings are suitable for demolition and over $50 \%$ of the buildings are characterized by technical wear at the level of $51-70 \%$. (Resolution No. XLIV / 826/12 of Lodz City Council of 29 June 2012 ...). Rent arrears are another problem. In 2013, the share of housing in Poland in which tenants were in arrears with their payments amounted to $40.5 \%$ in municipality housing stock, $41.4 \%$ in cooperative stock and $24.3 \%$ in SHA stock. The total amount of arrears in the entire housing resources amounted to over PLN 2 billion (Housing in 2013....p. 30).

In 2010, the Ministry of Infrastructure presented the premises for drafting the Act on Social Housing Resources for Rent, Social Housing Groups and Amendments to Certain Other Acts, according to which social housing foundations would be, among others, one of the new entities supporting social housing for rent. The draft does not specify, however, detailed rules for their operation, although it is stipulated that the activities of this kind of foundation, on the basis of the existing legislation, cannot be financed with public funds. It can, therefore, be said that the idea of non-profit activities other than SHAs appeared a few years ago, but ultimately no relevant law has been passed, hence the idea has never been implemented (Premises for the Draft of the Act on Social Housing Resources For Rent... 2010, pp. 68-71, see also: MUCZYŃSKI 2010, pp. 7-25).

The problem lies in the fact that Poland lacks comprehensive solutions that would not only contribute to an increase in the quantity and quality of housing stock, but would also socially and professionally activate people with low incomes, at the same time assisting in forming a sense of identity with the community. Such solutions are necessary as, in many cities, one can find deprived areas inhabited by people with very low incomes, often affected by structural unemployment. Even if a municipality or a SHA decided to modernize such neighborhoods, the problem would not be solved as people who inhabit them would not have sufficient financial resources for their proper maintenance. These kinds of locations require a non-profit developer that not only creates appropriate 
living conditions, but also helps the residents leave the sphere of poverty by organizing training and career counselling.

Are there, however, growth prospects for such entities under Polish conditions? According to the author, under the current institutional conditions there are not. This is due to several reasons.

Firstly, the question of which entities should come out with the initiative of such an activity rises non-profit organizations dealing, for example, with social exclusion, or for-profit developers. Social organizations often do not have experience managing such large projects and would hence need a partner. Developers, on the other hand, would primarily require financial support motivating them to take up this kind of activity.

It is worth noting that, in Poland, the idea of social economy, based on taking actions aimed at specific individuals, organizations or communities that would allow them to make sovereign decisions about the purpose and forms of their activity to a much larger degree, is becoming increasingly popular. This is realized by various cooperatives, including social cooperatives, Social Integration Centers or hybrid institutions, such as social enterprises that operate in the form of partnerships or networks of enterprises. They offer, among others, educational and advisory services, transport services for the disabled, jobs for specific groups that find it difficult to obtain employment, as well as the allocation of funds to non-profit organizations or disadvantaged groups (hybrid institutions). Especially the fund allocation related form of activity resembles, to some extent, the support of investors for non-profit developers in the United States. Poland, however, lacks a comprehensively developed model for the activities of such entities (FRĄCZAK, WYGNAŃSKI 2008, pp. 14- 32) .

Secondly, and most importantly, the growth of non-profit development activity requires significant institutional changes, both in terms of legal regulations concerning the principles of operation of such entities as well as their funding. It is worth noting that preferential loans in the case of SHAs would have to be really low-interest ones. Rents for flats for low-income people cannot be too high, but as the same time have to be enough to cover maintenance costs and the repayment of credit instalments. Perhaps interest-free loans or tax credits used in the USA would, therefore, be a better form of support.

Based on the above, the author believes the current institutional conditions in Poland to prevent the growth of non-profit development activity discussed in the paper.

\section{Summary}

Since the 1990s, Polish residential construction has experienced numerous changes which are unfavorable for low-income households. The number of flats completed by municipalities as well as housing cooperatives, which additionally do not have the capacity to build flats on the principle of cooperative tenant right to property due to the lack of financial support from the state, has decreased. In the USA, flats for the most needy are built, among others, by non-profit developers. In Poland, however, there is a lack of housing available for rent to people with low incomes. The existing Social Housing Associations only construct housing for people with average incomes, without engaging in other activities that ensure the development of the local community, including services aimed at improving the living conditions of residents. According to the author, the current activity of SHAs and municipalities is not sufficient to solve the biggest housing problem of the Polish society, i.e. the limited availability of housing. Households with low incomes generally have only one "breadwinner" and are often made up of several people; thus they are threatened by unemployment to the largest extent. It is therefore necessary to create comprehensive solutions that increase their ability to obtain higher income from work to improve their living conditions, including their housing situation. Thus, non-profit development activity organized along the lines of the solutions adopted in the United States could significantly help to alleviate the existing problems. Although the government is currently working on a package of some housing policy instruments, their extent appears to be insufficient to overcome the problem of housing availability. Measures that enable the development of social enterprises which would support non-profit organizations in the construction of housing for those most in need and in the revitalization of run-down neighborhoods are necessary. Their creation, however, is not possible under the currently existing institutional conditions, as so far the principles of the functioning of such entities and, above all, their financing in the form of tax exemptions or interest-free loans, have not been developed in our country. Another solution could be the expansion 
in the form of activity of Social Housing Associations to encompass the needs of people with lower incomes and the extension of the availability of sources of funding. It also seems necessary to recommend better access to information about the experiences of foreign entities, which this publication attempts to do to a certain extent. Another important conclusion which can be formulated draws attention to the desirability of undertaking, in the future, conceptual-analytical work aimed at developing the assumptions for the Polish model of non-profit development activity in the context of systems of housing construction used in the country, as well as taking advantage of the possibilities offered by the public-private partnership formula.

\section{References}

BlACK D., 2014, Low-Income Housing Tax Credits: Affordable Housing Investment Opportunities for Banks, Office of the Comptroller of the Currency, Washington.

BRATT R., 2007, Should we Foster the Non - Profit Housing Sector as Developers and Owners of Subsidized Rental Housing? MA: Joint Center for Housing Studies, Harvard University.

BRATT R. G., KeYES L. C., 1998, Challenges Confronting Nonprofit Housing Organizations' Self-Sufficiency Programs, Housing Policy Debate, Volume 9, Issue 4 Fannie Mae Foundation.

Budżety gospodarstw domowych w 2013 roku (Household Budgets in 2013), GUS (CSO), Warszawa 2014, p. 48.

Chinatown CDC website: http://www.chinatowncdc.org/index.php?option=com_content\&view= article\&id=64\&Itemid=74, (access: 22.08.2015).

Chung A., 2004, Bridging Sectors: Partnerships Between Nonprofits and Private Developers, Joint Center for Housing Studies of Harvard University, September.

ClarKe R., 2015, The Low Income Housing Tax Credit (LIHTC): Challenges Presented by the Onset of Year 15 in the St. Louis Region, Federal Reserve Bank of St. Louis.

D'Arcy É., KeOgh G., 2002, The Market Context of Property Development Activity, [in:] S. Guy, J. Henneberry (ed.), Development and Developers: Perspectives of Property, Blackwell Science Ltd, Oxford.

DAVIS T., 2007, The Real Estate Developer's Handbook: How to Set Up, Operate, and Manage a Financially Successful Real Estate Development, Atlantic Publishing Group Inc., Ocala.

Denavas - Walt C., Proctor B. D., 2014, Income and Poverty in the United States: 2013. Current Population Reports, U.S. Census Bureau, Washington.

DitTMANN I., 2014, Setting Offer Prices by Housing Developers - Selected Issues in the Light of the Literature Studies, Real Estate Management and Valuation, Vol. 22, iss. 4.

Dreier P., HUlchanSKI J. D., 1993, The Role of Nonprofit Housing in Canada and the United States: Some Comparisons, Housing Policy Debate, Vol. 4 iss. 1.

Eurostat, at: http://ec.europa.eu/eurostat/statistics-explained/index.php/Housing_ statistics/pl (access: 4.09.2015).

FisHeR J.D., MARTIN R.S., MOSBaUgh P. 1991. The Language of Real Estate Appraisal, Dearborn Financial Publishing Inc., Chicago.

FrĄCZAK P., WYGNAŃSKI J.J., (ed.) 2008, Polski model ekonomii społecznej. Rekomendacje dla rozwoju (The Polish Model of Social Economy. Recommendations for Development), Fundacja Inicjatyw Społeczno - Ekonomicznych (Foundation for Social and Economic Initiatives), Warszawa.

FriedmAN M., 1968, 81-82, 87, quoted after: R. Bratt, 2007, Should we Foster the Non - Profit Housing Sector as Developers and Owners of Subsidized Rental Housing? MA: Joint Center for Housing Studies, Harvard University.

GAWRON H., 2006, Optacalność inwestowania na rynku nieruchomości (Cost-effectiveness of Investing in Real Estate), Wydawnictwo Akademii Ekonomicznej w Poznaniu, Poznań.

Gospodarka mieszkaniowa w 2013 r. (Housing in 2013 ), GUS (CSO), Warszawa 2014.

HetTINGER W. S., 2005, Low Income Housing Tax Credits. Strategies for Year 15, Communities\&Banking.

KäLIN CH. H., 2005, International Real Estate Handbook. Acquisition, Ownership and Sale of Real Estate. Residence, Tax and Inheritance Law, John Wiley \& Sons Ltd, Chichester, England.

KIMURA D., 2015, LIHTC Survives Tax Reform Draft; Big Changes Proposed, at: http://www.housingfinance.com/finance/lihtc-survives-tax-reform-draft-big-changesproposed_o (access: 1.09.2015).

KUCHARSKA - STASIAK E., 2006, Nieruchomość w gospodarce rynkowej (Real Estate in a Market Economy), PWN, Warszawa. 
Los Angeles Conservancy website: https://www.laconservancy.org/locations/28th-streetapartments, (access: 22.08.2015).

ŁASZEK J., 2004, Sektor nieruchomości mieszkaniowych w Polsce. Stan i perspektywy rozwoju (The Residential Real Estate Sector in Poland. Its Status and Prospects of Development). Szkoła Główna Handlowa (Warsaw School of Economics), Warszawa.

MUCZYŃSKI A., 2011, Gospodarowanie gminnymi zasobami lokalowymi z perspektywy polityki mieszkaniowej (Management of Municipal Housing Resources from the Perspective of the Housing Policy), Studia i Materiały Towarzystwa Naukowego Nieruchomości (Studies and Materials of the Polish Real Estate Scientific Society), Vol. 19, Issue 2.

Peiser R., HAMilton D., 2015, From Small Private Market Local Entrepreneurs Towards Sophisticated Enterprise, G. Squires, E. Heurkens (ed.), International Approaches to Real Estate Development, Routledge, New York.

PISANI R., PISANI R., 2001, How To Be a Successful Developer, E-Rights/E-Reads Ltd., New York.

Rozporzadzenie Rady Ministrów z dnia 7 listopada 2007 roku w sprawie warunków i trybu udzielania kredytów i pożyczek ze środków Krajowego Funduszu Mieszkaniowego oraz niektórych wymagan dotyczacych lokali i budynków finansowanych przy udziale tych środków, Dz. U. 212. poz. 1556, z późn. zm. (Regulation of the Council of Ministers of 7 November 2007 on conditions and procedures for granting credits and loans by the National Housing Fund and some requirements concerning the premises and buildings financed with these funds, Journal of Laws, 212. Item 1556, as amended.).

SCHOONBRODT R., 1987, Essai sur la destruction des villes et des campagnes, Pierre Mandaga, Liège.

Sytuacja mieszkaniowa w Polsce w 2012 roku. Raport, Polski Związek Firm Deweloperskich (The Housing Situation in Poland in 2012. The Report of the Polish Association of Developers), Warszawa 2012.

The Low Income Housing Tax Credit for Nonprofits Developing Rural Rental Housing, January 2004, at: https://www.hudexchange.info/resources/documents/Low-Income-Housing-Tax-CreditSummary.pdf (access: 16.09.2015).

U.S. Census, https://www.census.gov/construction/nrs/pdf/uspricemon.pdf, at: http://www.census.gov/hhes/www/cpstables/032010/hhinc/new01_001.htm, (access: 1.09.2015).

U.S. Department of Housing and Urban Development (HUD), at: http:/ / www.huduser.org/portal

/ushmc/hi_HOR.html (access: 16.09.2015).

Uchwala $n r$ XLIV/826/12 Rady Miejskiej w Łodzi z dnia 29 czerwca 2012 r. w sprawie przyjęcia Wieloletniego programu gospodarowania mieszkaniowym zasobem Miasta Łodzi na lata 2012 2016 (Resolution No. XLIV/826/12 of Lodz City Council of 29 June 2012 on adopting a multiannual program of management of the housing resources of the City of Lodz for the years 20122016).

Ustawa z dnia 1995 roku o niektórych formach popierania budownictwa mieszkaniowego, Dz.U. 1995 nr 133 poz. 654, z późn. zm (Act of 1995 on Certain Forms of Support for Residential Construction, Journal of Laws, 1995 No. 133, Item 654, as amended).

Ustawa z dnia 10 września 2015 r. o zmianie ustawy o niektórych formach popierania budownictwa mieszkaniowego oraz niektórych innych ustaw, Dz. U. 2015 nr 0 poz. 1582 (The Act of 10 September 2015 Amending the Act on Certain Forms of Support for Residential Construction and Certain Other Legislation, Journal of Laws 2015 No. 0 Item 1582).

WendLING P., 2008, Immobilier Strasbourg. Agglomération et environs, Petit Futé.

Założenia do projektu ustawy o społecznym zasobie mieszkań czynszowych, społecznych grupach mieszkaniowych oraz o zmianie niektórych innych ustaw (Premises for the Draft of the Act on Social Housing Resources for Rent, Social Housing Groups and Amendments to Certain Other Acts), Ministerstwo Infrastruktury (Ministry of Infrastructure), Warszawa 2010. 